\title{
Nitrogen and Potassium Fertilization in the Initial Growth of Annona crassiflora Mart.
}

\author{
Andréia Mendes da $\operatorname{Costa}^{1}$ (D), Leandro $\operatorname{Carlos}^{1}$ (D), Patrícia Oliveira da Silva ${ }^{1}$ (D), \\ Kássia de Paula Barbosa ${ }^{1}$ (D), Carlos Ribeiro Rodrigues ${ }^{1}$
}

${ }^{1}$ Programa de Pós-graduação em Ciências Agrárias, Departamento de Agronomia, Instituto Federal Goiano - IF Goiano, Rio Verde/GO, Brasil

\begin{abstract}
Annona crassiflora Mart. presents medicinal and food potential, and is also used in the recovery of degraded areas, however, little is known about its nutritional requirements. The aim of this work was to analyze the initial growth of $A$. crassiflora submitted to nitrogen and potassium fertilization. The experiment was conducted with a complete randomized block design with four replicates, each consisting of five nitrogen and potassium doses $\left(0,50,100,150\right.$ and $\left.200 \mathrm{mg} \mathrm{dm}^{-3}\right)$. Results were submitted to regression analysis. The species showed significant response for nitrogen fertilization regarding biometric variables, biomass, DQI and nutritional contents at doses of 100 to $200 \mathrm{mg} \mathrm{dm}^{-3}$. On the other hand, potassium only influenced DQI, nutritional content and accumulation of $A$. crassiflora seedlings.
\end{abstract}

Keywords: seedlings, nitrogen doses, potassium doses. 


\section{INTRODUCTION}

Annona crassiflora Mart. belongs to the Annonaceae family, popularly known in Brazil as "marolo" or "Araticum" (Botrel et al., 2016). This species stands out among the native fruits of the Cerrado biome due to its socioeconomic importance (Ribeiro et al., 2016a). Moreover, it represents a promising alternative for family farming due to its extractive exploitation; a sector that is quickly expanding in the current Brazilian agricultural scenario (Valadares et al., 2015). This species also has great medicinal and food potential, as it is recommended for treating diarrhea, rheumatism and as anti-tumor. In addition, it has been used in cosmetics against scalp infections, as it contains compounds with therapeutic indications (Bailão et al., 2015).

However, with the rapid expansion of agriculture in Cerrado regions accompanied by reduction in native vegetation, many species of this domain are threatened, including $A$. crassiflora. Thus, in order to minimize environmental impacts and promote maintenance of the native vegetation, programs for the recovery of these disturbed areas are necessary (Ribeiro et al., 2016b). Accordingly, it is also necessary to understand the silvicultural behavior of this species, mainly in relation to fertilization, considering that little is known about the behavior of this species in Cerrado regions.

Soils of the Brazilian Cerrado are highly weathered with low natural fertility, high acidity, low cation exchange capacity, low organic matter and high aluminum concentration (Farias et al., 2016). All these factors influence seedling production of some species to a certain extent. Therefore, studies have used nitrogen and potassium fertilizations to increase seedling production in Brazilian Cerrado regions.

Nitrogen $(\mathrm{N})$ acts in the enzymatic system of plants. It is an essential component of the ribulose 1,5-bisphosphate carboxylase/oxygenase (RuBP carboxylase - "Rubisco") enzyme, a key enzyme for carbon fixation, participating in several physiological processes directly related to cell division and stretching, resulting from the performance of the assimilatory system (Mendes et al., 2013).

Potassium (K) acts in several metabolic functions of plants. It is present in cell cytoplasm and is considered the largest osmotic cellular cationic agent. It also regulates stomata opening and closing, acts in controlling assimilation of the internal $\mathrm{CO}_{2}$ concentration in chloroplasts, in photosynthesis, activating enzymes, and distributing/storing carbohydrates (sucrose) through the membrane and synthesis of proteins (Sousa et al., 2014).

Even with knowledge on the importance of nitrogen and potassium fertilization, information about the effect of these nutrients on the initial growth of native Cerrado species is scarce, especially for A. crassiflora. Thus, the aim of this study was to evaluate nitrogen and potassium fertilization in the growth and establishment of $A$. crassiflora during the nursery/seedling phase.

\section{MATERIAL AND METHODS}

The experiment was conducted in greenhouse belonging to the Federal Institute of Goiás - Rio Verde Campus. The species used in the experiment was Annona crassiflora, and seeds were collected in the municipality of Felixlândia - Minas Gerais.

The soil used in the study is classified as haplortox (EMBRAPA, 2006). Samples were collected from 5 different points in the $0-20 \mathrm{~cm}$ depth layer, representing a composite sample for chemical and physical characterization (EMBRAPA, 2009). Physical analysis was performed for granulometric determination of fine air-dried soil according to the pipette method (EMBRAPA, 1997). The granulometric analysis indicated that the soil used consisted of $50 \%$ clay, $18 \%$ silt and $32 \%$ sand (Table 1 ); while the chemical analysis (Table 1) showed that the soil base saturation in natural condition was around $12 \%$, calcium, magnesium and phosphorus were below recommended levels, and saturation was increased by bases according to treatments. After fertilization, soil presented adequate attributes for cultivation.

Two different experiments were carried out; one using nitrogen doses and another with potassium doses. The experimental design was completely randomized and composed of 5 nitrogen and potassium doses $\left(0,50,100,150,200 \mathrm{mg} \mathrm{dm}^{-3}\right)$ with 4 replicates, corresponding to a total of 20 experimental plots for each nutrient.

Soil acidity was corrected with limestone and incubated for a period of 20 days seeking to achieve $\mathrm{V}=60 \%$, according to van Raij (1981).

The suggested basic fertilization was performed in all experimental units according to the following doses and sources: $300 \mathrm{mg}$ of phosphorus $/ \mathrm{dm}^{3}$ of 
Table 1. Soil chemical and texture characteristics for A. crassiflora seedlings before and after fertilization.

\begin{tabular}{lccccccc}
\multicolumn{1}{c}{ Attributes } & Natural & K 0 & K 50 & K 100 & K 150 & K 200 & Nitrogen \\
$\mathrm{pH}\left(\mathrm{CaCl}_{2}\right)$ & 4.30 & 4.80 & 4.80 & 4.80 & 4.70 & 4.80 & 5.30 \\
$\mathrm{~K}\left(\mathrm{cmolc} \mathrm{dm}^{-3}\right)$ & 0.11 & 0.23 & 0.32 & 0.40 & 0.51 & 0.51 & 0.45 \\
$\mathrm{Ca}^{2+}\left(\mathrm{cmolc} \mathrm{dm}^{-3}\right)$ & 0.40 & 1.67 & 1.99 & 1.92 & 2.24 & 1.85 & 1.79 \\
$\mathrm{Mg}^{2+}\left(\mathrm{cmolc} \mathrm{dm}^{-3}\right)$ & 0.10 & 1.47 & 1.70 & 1.51 & 1.97 & 1.44 & 1.30 \\
$\mathrm{Al}^{3+}\left(\mathrm{cmolc} \mathrm{dm}^{-3}\right)$ & 0.30 & 0.04 & 0.07 & 0.08 & 0.05 & 0.03 & 0.02 \\
$\mathrm{H}+\mathrm{Al}\left(\mathrm{cmolc} \mathrm{dm}^{-3}\right)$ & 4.50 & 4.17 & 4.93 & 4.88 & 4.93 & 4.17 & 3.14 \\
$\mathrm{P}(\mathrm{Mel})\left(\mathrm{mg} \mathrm{dm}^{-3}\right)$ & 6.00 & 15.54 & 15.06 & 17.56 & 13.42 & 15.01 & 11.13 \\
$\mathrm{SB}\left(\mathrm{cmolc} \mathrm{dm}^{-3}\right)$ & 0.61 & 3.37 & 4.01 & 3.83 & 4.72 & 3.80 & 3.54 \\
$\mathrm{t}(\mathrm{cmolc} \mathrm{dm})^{-3}$ & 0.91 & 3.41 & 4.08 & 3.91 & 4.77 & 3.83 & 3.56 \\
$\left.\mathrm{~T}(\mathrm{cmolc} \mathrm{dm})^{-3}\right)$ & 5.11 & 7.54 & 8.94 & 8.71 & 9.65 & 7.97 & 6.68 \\
$\mathrm{~V}(\%)$ & 11.99 & 44.69 & 44.85 & 43.97 & 48.91 & 47.68 & 52.99 \\
Clay & 50 & 50 & 50 & 50 & 50 & 50 & 50 \\
Silt & 18 & 18 & 18 & 18 & 18 & 18 & 18 \\
Sand & 32 & 32 & 32 & 32 & 32 & 32 & 32 \\
\hline
\end{tabular}

Natural: original non-fertilized soil; K0 to K200: soil with basic fertilization, with different potassium levels (from 0 to $200 \mathrm{mg}^{-3}$ ); Nitrogen: soil fertilized by nitrogen treatments; $\mathrm{pH}$ : potential of hydrogen; K: potassium; Ca: calcium; Mg: magnesium; CEC: cation exchange capacity; Al: aluminum; $\mathrm{H}+\mathrm{Al}$ : hydrogen plus aluminum; P: phosphorus; SB: Sum of bases; t: effective CEC; T: CEC at pH 7.0; V (\%): Base Saturation.

soil (triple superphosphate and monoammonium phosphate); $40 \mathrm{mg}$ of sulfur/ $\mathrm{dm}^{3}$ of soil (ammonium sulfate and potassium sulphate); $0.5 \mathrm{mg}$ of boron $/ \mathrm{dm}^{3}$ of soil (boric acid P.A.); $1.5 \mathrm{mg}$ of copper $/ \mathrm{dm}^{3}$ of soil (copper sulfate P.A.); $3.0 \mathrm{mg}$ of manganese $/ \mathrm{dm}^{3}$ of soil (manganese sulphate P.A.); $5.0 \mathrm{mg}$ of zinc/ $\mathrm{dm}^{3}$ of soil (zinc sulfate P.A.) and $0.1 \mathrm{mg}$ of molybdenum/ $/ \mathrm{dm}^{3}$ of soil (ammonium molybdate P.A.); and $200 \mathrm{mg}$ of nitrogen $/ \mathrm{dm}^{3}$ of soil (monoammonium phosphate and urea) and $180 \mathrm{mg}$ of potassium $/ \mathrm{dm}^{3}$ of soil (potassium chloride) when necessary (Carlos et al., 2014).

Due to the morphophysiological dormancy, seeds were arranged in sowing equipment using sand over a layer of gravel substrate. A layer of carbonized rice husk was added on the top of seeds for period of approximate eight months. Soon after seeds were removed from the sowing equipment, gibberellic acid $\left(\mathrm{GA}_{3}\right)$ at $500 \mathrm{ppm}$ was applied for a period of 24 hours at room temperature for complete imbibition. Subsequently, seeds were rinsed in hypochlorite and placed to germinate in vermiculite, according to the modified methodology of Silva et al. (2007) and Braga et al. (2014).

After radicle protrusion, pre-germinated seeds were transplanted by sowing a single seed in each 3.5-liter pot containing soil and the established treatments. Irrigation was maintained at $60 \%$ of field capacity according to the International Association of Engineering Geology (IAEG, 1979).
During the nursery phase, corresponding to the period between January and August, the morphological parameters evaluated were: plant height between neck and stem apex measured with the help of a millimeter ruler, with results expressed in $\mathrm{cm}$; and stem diameter using a digital caliper, with results expressed in $\mathrm{mm}$.

Seedlings were removed from pots at the end of experiments and separated into stems, leaves and roots. Subsequently, they were dried in a forced air circulation oven at $65^{\circ} \mathrm{C}$ until reaching constant weight. After drying, the material was weighed in an analytical digital scale to obtain the biomass. Then, the dry mass of leaves (DML), stem (DMSt), roots (DMR), shoots (DMSh) and total dry mass (TDM) were determined, and results were expressed in g plant- ${ }^{1}$. With these parameters, the following seedling quality indexes were calculated: height-to-diameter ratio (H/D), root-to-shoot ratio (R/S) and Dickson Quality Index (DQI), according to Dickson et al. (1960).

For quantification of contents and nutritional accumulation of shoot and root systems after being dried, the plant material was milled in a Willye type mill and $0.1 \mathrm{~g}$ of $\mathrm{N}$ and $0.5 \mathrm{~g}$ of $\mathrm{K}$ were weighed for extraction of each macronutrient. $\mathrm{N}$ extraction was carried out by wet digestion using nitrogen distiller and determined by titration, while for K extraction, the material was calcined in a muffle furnace and readings were performed by flame emission photometer (EMBRAPA, 2009). 
Results were submitted to analysis of variance at $0.05 \%$ probability level and regression analysis was performed when effect was found using the SISVAR 5.3 software (Ferreira, 2011).

\section{RESULTS}

Nitrogen fertilization had significant influence on all variables analyzed, except for height-to-diameter ratio $(\mathrm{H} / \mathrm{D})$ and root-to-shoot ratio $(\mathrm{R} / \mathrm{S})$.

Results for diameter, height and number of leaves are presented in Figure 1, with the first two adjustments using quadratic equations and the last using linear equation. The highest estimated measurements for height and diameter were $7.97 \mathrm{~cm}$ and $9.07 \mathrm{~mm}$ obtained for doses of $\mathrm{N} 94.5$ and $89 \mathrm{mg} \mathrm{dm}^{-3}$, respectively. Maximum leaf yield was 5.23 leaves for the $\mathrm{N}$ dose of $200 \mathrm{mg} \mathrm{dm}^{-3}$. Considering that nitrogen is one of the nutrients most required by plants in higher amounts, being directly related to growth, plants well-nourished in $\mathrm{N}$ have great capacity to assimilate $\mathrm{CO}_{2}$ and to synthesize carbohydrates during photosynthesis.

Dry mass data presented quadratic adjustments, in which doses that presented the highest biomass yields were the following: $89.5 \mathrm{mg}$ of $\mathrm{N}$ per $\mathrm{dm}^{-3}$ of soil for DMSh; $87.85 \mathrm{mg}$ of $\mathrm{N}$ per $\mathrm{dm}^{-3}$ of soil for DML; $91.66 \mathrm{mg}$ of $\mathrm{N}$ per $\mathrm{dm}^{-3}$ of soil for DMSt; $94.5 \mathrm{mg}$ of $\mathrm{N}$ per $\mathrm{dm}^{-3}$ of soil for DMR; and $92 \mathrm{mg}$ of $\mathrm{N}_{\text {per }} \mathrm{dm}^{-3}$ of soil for TDM (Figure 2).

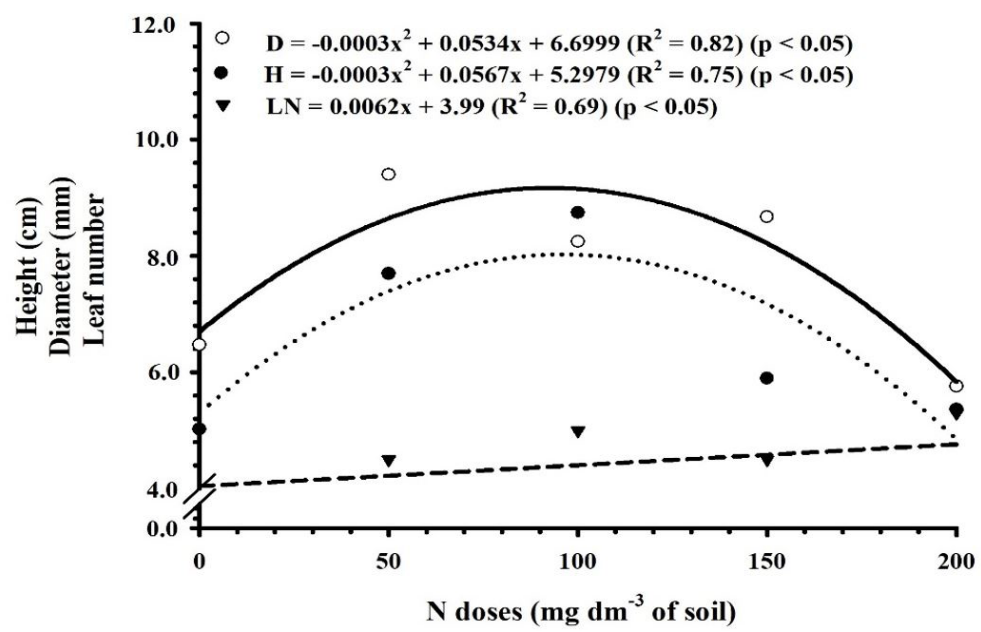

Figure 1. Height, diameter and number of A. crassiflora leaves in response to nitrogen fertilization.

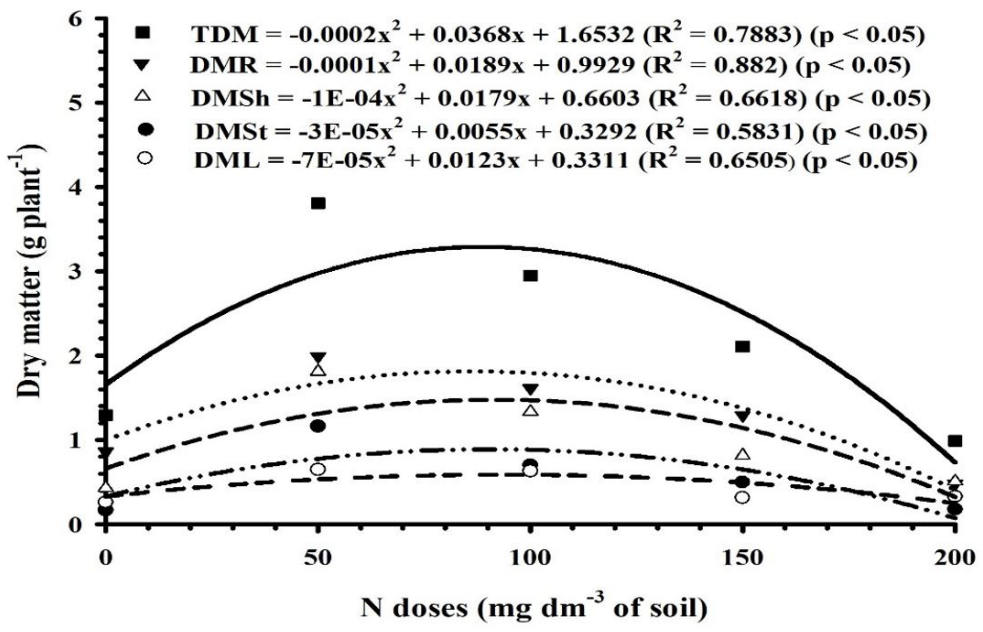

Figure 2. Shoot, leaf, stem, root dry mass and total dry mass of A. crassiflora plants submitted to different nitrogen fertilization doses. 
Among the morphological attributes that determine the quality of seedlings, only the Dickson Quality Index (DQI) was significant, reaching maximum value of 2.05 at $\mathrm{N}$ dose of $95 \mathrm{mg}$ per $\mathrm{dm}^{3}$ of soil, adjusted for the quadratic regression model according to Figure 3.

Significant effect for the $\mathrm{N}$ content in stem was observed with maximum estimated concentration of $32.29 \mathrm{~g} \mathrm{~kg}^{-1}$ obtained at dose of $200 \mathrm{mg} \mathrm{dm}^{-3}$ with linear adjustment, and $33.58 \mathrm{~g} \mathrm{~kg}^{-1}$ in roots obtained at dose of $144.25 \mathrm{mg} \mathrm{dm}^{-3}$ with quadratic adjustment. No significant differences were found for the $\mathrm{N}$ content in leaves (Figure 4A).

In relation to nutrient accumulation (Figure 4B), significant effect was only observed for leaves and roots, in which leaves presented maximum accumulation of $18.14 \mathrm{mg}$ plant $^{-1}$ for $\mathrm{N}$ dose of $87.76 \mathrm{mg} \mathrm{dm}^{-3}$, and maximum accumulation for roots was $60.11 \mathrm{mg} \mathrm{plant}^{-1}$ at dose of $97.65 \mathrm{mg} \mathrm{dm}^{-3}$. No significant difference was observed for stem.

For potassium fertilization, no statistical difference was found for the evaluated characteristics, except for DQI, in which dose of $150 \mathrm{mg} \mathrm{dm}^{-3}$ was higher; however, there was no regression adjustment for this variable (Table 2). The behavior of this species suggests that lower K mobilization occurred during the initial growth stages for the plant's biochemical reactions, thus negatively influencing the growth and quality of seedlings, and with only significant difference $(p<0.05)$ for accumulation and allocation of the nutritional content.

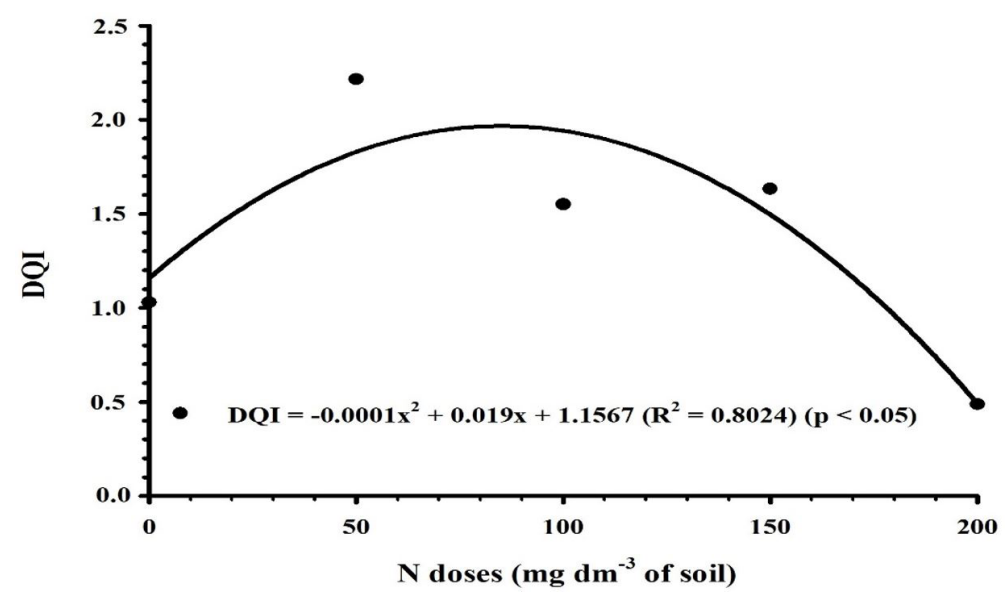

Figure 3. Dickson quality index (DQI) of A. crassiflora seedlings under different nitrogen fertilization doses.
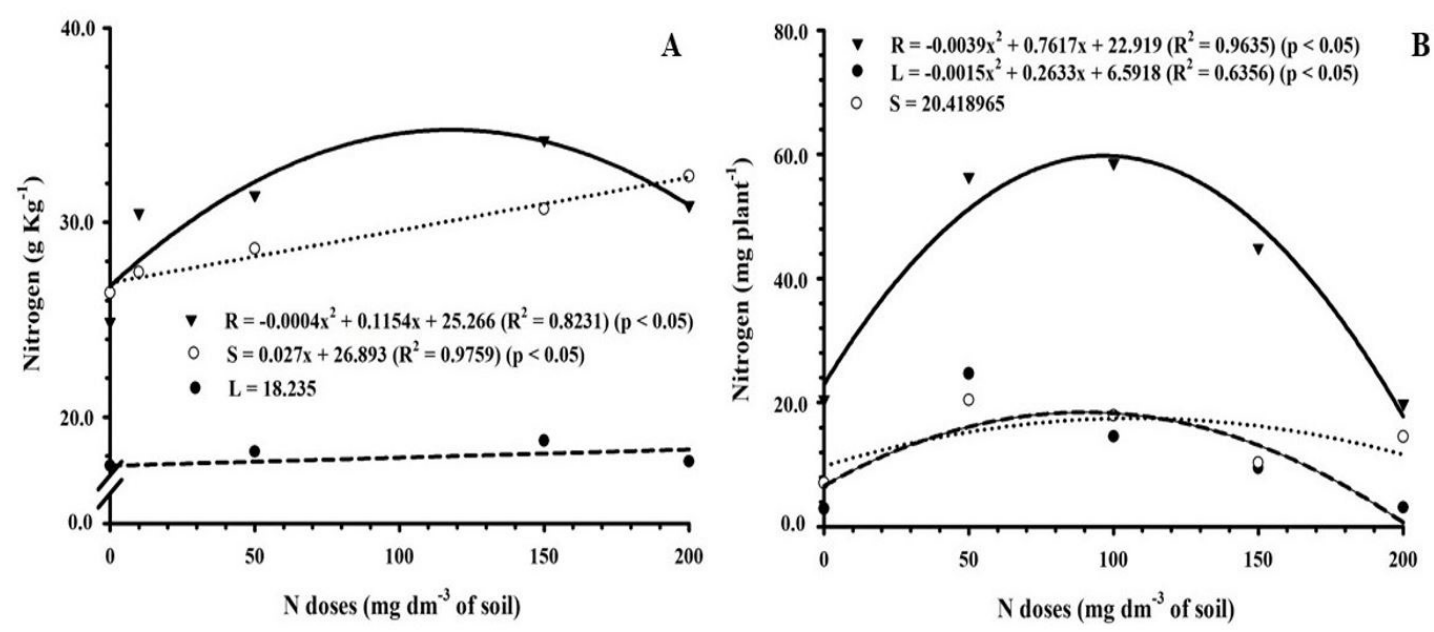

Figure 4. Nitrogen content (A) and accumulation (B) in leaves, stem and roots of A. crassiflora seedlings in relation to $\mathrm{N}$ fertilization doses. 
Table 2. Mean values of biometric variables in relation to potassium doses (K). D-diameter, H-height, NL-number leaves, DML-dry mass of leaves, DMSt- stem, DMR-roots, DMSh-shoots, TDM-total dry mass, H/D-height-to-diameter ratio, R/S-root-to-shoot ratio and DQI-Dickson Quality Index.

\begin{tabular}{|c|c|c|c|c|c|c|c|c|c|c|c|c|c|c|c|c|c|c|c|c|c|c|}
\hline \multirow{2}{*}{$\frac{\mathrm{K} \text { doses }}{\mathrm{mg} \mathrm{dm}^{-3}}$} & \multicolumn{2}{|c|}{ D } & \multicolumn{2}{|c|}{$\mathbf{H}$} & \multirow{2}{*}{\multicolumn{2}{|c|}{ NL }} & \multicolumn{2}{|c|}{ DML } & \multicolumn{2}{|c|}{ DMSt } & \multicolumn{2}{|c|}{ DMR } & \multicolumn{2}{|c|}{ DMSh } & \multicolumn{2}{|c|}{ TDM } & \multirow{2}{*}{\multicolumn{2}{|c|}{$R / S$}} & \multirow{2}{*}{\multicolumn{2}{|c|}{ H/D }} & \multirow{2}{*}{\multicolumn{2}{|c|}{ DQI }} \\
\hline & $\mathbf{m n}$ & & $\mathrm{cm}$ & & & & g & & g & & g & & g & & g & & & & & & & \\
\hline 0 & 9.4 & a & 12.9 & a & 7.5 & a & 1.5 & a & 0.9 & a & 3.6 & a & 2.4 & a & 6.0 & $\mathrm{a}$ & 1.3 & 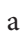 & 0.7 & a & 2.8 & b \\
\hline 50 & 9.2 & $\mathrm{a}$ & 7.9 & a & 5.8 & a & 2.1 & a & 0.8 & a & 1.6 & a & 2.9 & $\mathrm{a}$ & 4.5 & a & 1.2 & $\mathrm{a}$ & 1.1 & $\mathrm{a}$ & 1.4 & b \\
\hline 100 & 7.5 & a & 7.2 & $\mathrm{a}$ & 4.5 & a & 1.0 & a & 0.8 & a & 3.0 & a & 1.8 & $\mathrm{a}$ & 4.8 & $\mathrm{a}$ & 1.5 & a & 0.9 & a & 2.1 & b \\
\hline 150 & 17.8 & a & 14.5 & a & 7.8 & a & 3.5 & a & 2.5 & a & 8.9 & a & 6.0 & a & 14.9 & a & 1.4 & a & 1.2 & a & 6.9 & $\mathrm{a}$ \\
\hline 200 & 10.8 & a & 10.2 & a & 6.3 & $\mathrm{a}$ & 0.9 & $\mathrm{a}$ & 1.2 & a & 2.8 & a & 2.1 & a & 4.9 & $\mathrm{a}$ & 1.3 & $\mathrm{a}$ & 1.0 & a & 2.3 & b \\
\hline
\end{tabular}

Means followed by the same letter did not differ from each other $(\mathrm{p}<0,05)$.
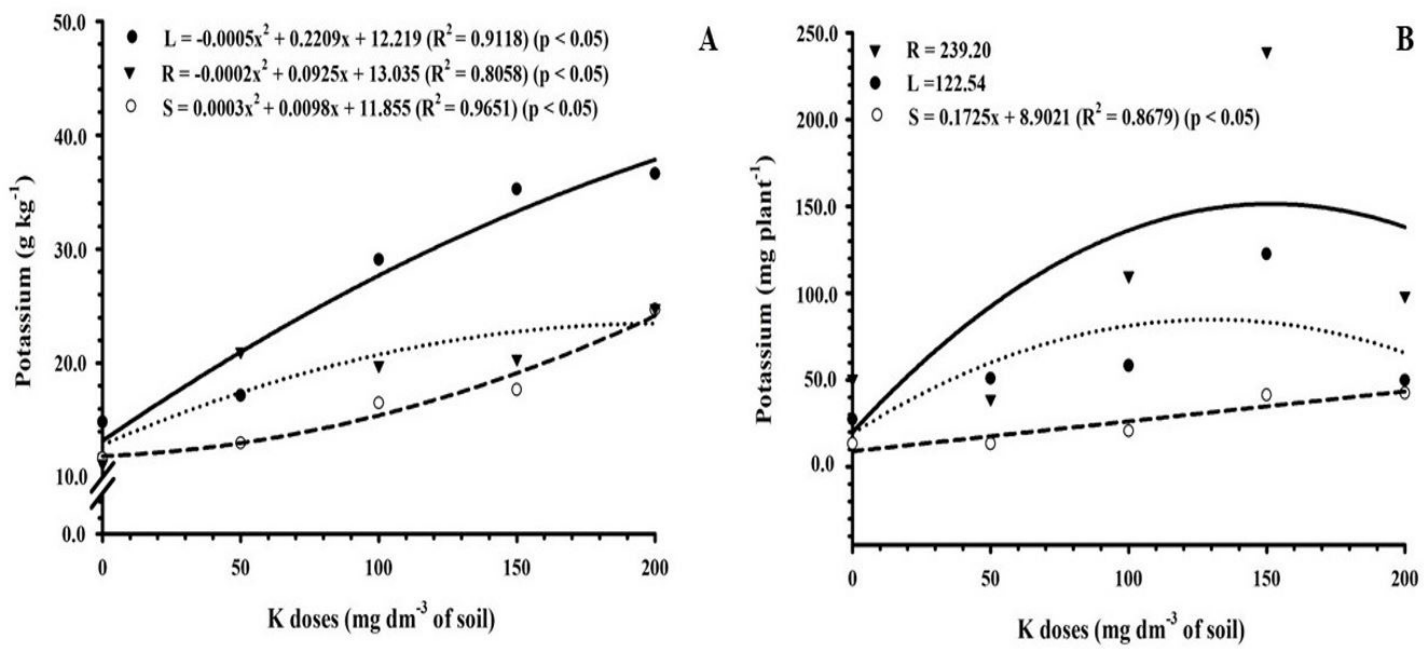

Figure 5. Potassium content (A) and accumulation (B) in leaves, stem and roots of $A$. crassiflora seedlings in relation to $\mathrm{K}$ fertilization doses.

In general, a trend towards higher growth rates at $\mathrm{K}$ dose of $150 \mathrm{mg} \mathrm{dm}^{-3}$ was observed, and the dose presented statistically higher result for DQI; a strong indication that this would be the recommended dose for the species under study.

The $\mathrm{K}$ content in the tissues of $A$. crassiflora plants (Figure $5 \mathrm{~A}$ ) showed quadratic behavior. The highest $\mathrm{K}$ content was found at dose of $200 \mathrm{mg} \mathrm{dm}^{-3}$.

Nutrient accumulations presented no significant difference. The results obtained by calculating the potassium accumulation in plants indicated the highest values at $P$ doses of 137, 200 and $158 \mathrm{mg}$ per $\mathrm{dm}^{-3}$ of soil for leaves, stem and roots, respectively (Figure 5B).

\section{DISCUSSION}

Nitrogen fertilization had significant effect on the growth and quality of $A$. crassiflora seedlings. The results obtained in this study are similar to those found by Carnevali et al. (2016) in Stryphnodendron polyphyllum seedlings and by other authors in pitaia (Hylocereus undatus) (Almeida et al., 2014), canafistula (Peltophorum dubium) (Souza et al., 2013), gonçalo-alves (Astronium fraxinifolium) (Feitosa et al., 2011), açaí (Euterpe oleracea) (Oliveira et al., 2011) and angico-vermelho (Anadenanthera macrocarpa) (Gonçalves et al., 2012). Plants submitted to nitrogen doses generally present higher photosynthetic activity during the process of $\mathrm{CO}_{2}$ assimilation in the catalytic sites of the RuBP carboxylase enzyme in detriment of absorption, translocation and use of assimilates from senescent leaves to storage organs or growing tissues (Lötter et al., 2014).

Thus, studies involving growth analyses constitute an important indicator of the quality of $A$. crassiflora seedlings (Duarte et al., 2015), allowing describing in part the physiological and morphological behavior of the plant during a certain period of time, which 
would not be possible with just a simple record of the nutritional content yield (Pedó et al., 2014).

Both potassium and nitrogen showed high redistribution in plant tissues; however, when there is lack of $\mathrm{N}$ and $\mathrm{K}$, plants stimulate the activation of innumerable morphophysiological responses in order not to be impaired, reducing the photosynthetic rate, leaf osmotic potential and shoot growth (Magadlela et al., 2014). On the other hand, it increases the root system efficiency in order to obtain access to greater volume of soil (Rajan \& Veilumuthu Anandhan, 2016), which represents an important strategy for physiological, morphological and biochemical adaptation to ensure growth, cellular turgor maintenance, and absorption of sufficient water and nutrients to meet the plant needs. On the other hand, when the nitrogen and potassium content is excessive in the root system, they can cause toxicity, directly affecting growth (Saiz-Fernández et al., 2015; Deng et al., 2015). Thus, high doses can also be harmful.

Nutrient concentration in senescent leaves is entirely correlated with the presence of green leaves, and the increase in nutrient reabsorption efficiency considerably reduces $\mathrm{N}$ and $\mathrm{K}$ concentrations in green leaves. This flexibility indicates a strategy in the acquisition of biomass to reallocate photoassimilates, coordinating a series of processes related to the formation of several organs; however, adjustment in the efficiency of the internal use of nutrients is optional (Zhang et al., 2015).

A discrete response of seedlings in relation to potassium fertilization of morphological variables was also observed in vines (Platymenia foliolosa), where results similar to A. crassiflora were only found for the quality of seedlings and shoot height/diameter ratio (Duarte et al., 2015). In Dalbergia nigra seedlings, mathematical models appropriately adjusted to increasing $\mathrm{K}$ doses grown in Red-yellow Alic Latosol (LVAa), Mesotrophic Red-yellow Argisol (PVAm) and Dystrophic Red-Yellow Latosol soils (LVAd) were also not found (Gonçalves et al., 2014). This tendency also resembles the results observed by Gonçalves et al. (2010) in Mimosa caesalpiniaefolia seedlings using Dystrophic Red Latosol (LVd) and Red-Yellow Latosol (LVAs) soils as substrate, in which absence of effect of potassium fertilization in relation to the several evaluated growth characteristics was observed.

Compared with the obtained results, mahogany (Swietenia macrophylla), similar to the other species mentioned above, did not respond to $\mathrm{K}$ doses or even to nitrogen fertilization (Tucci et al., 2011). Although no effects were observed on seedlings, potassium supply is still important. The lack of response to this nutrient indicates that low amounts of $\mathrm{K}$ present in the soil are possibly sufficient to meet the plant needs. This explains the low nutritional requirement of A. crassiflora seedlings in terms of $\mathrm{K}$ (Gonçalves et al., 2014). Souza et al. (2010) and Cruz et al. $(2010,2011)$ found significant effect of $\mathrm{K}$ application on fedegoso seedlings (Senna macranthera), indicating that some forest species present greater nutritional $\mathrm{K}$ requirement when compared to the species under study.

The present study provides evidence of the positive effects promoted by nitrogen and potassium fertilization on A. crassiflora seedlings. In general, nitrogen affected the growth and quality of seedlings by altering several parameters, including $\mathrm{N}$ and $\mathrm{K}$ allocation and accumulation, which promoted an increase in height, diameter, shoot and root dry mass, which in turn promoted better Dickson quality index (DQI). Based on these variables, it was possible to evidence that the best nitrogen fertilization doses are 100 to $200 \mathrm{mg} \mathrm{dm}^{-3}$ while in the nursery stage. Although potassium fertilization showed discrete behavior for most characteristics evaluated under the conditions of this study, DQI, nutrient content and accumulation in A. crassiflora seedlings showed significant response.

\section{CONCLUSIONS}

Nitrogen fertilization positively influences the growth and quality of Annona crassiflora Mart. Seedlings at doses between 100 and $200 \mathrm{mg} \mathrm{dm}^{-3}$ under the conditions of this study.

The best quality of $A$. crassiflora seedlings regarding potassium fertilization was found for the dose of $150 \mathrm{mg} \mathrm{dm}^{-3}$.

\section{ACKNOWLEDGEMENTS}

To CAPES, for granting the scholarship, to the Laboratory of Hydraulics and Irrigation, Laboratory of Vegetable Tissue Culture, Laboratory of Agricultural Chemistry and Laboratory of Analysis of Soil and Foliar Tissue. To IF Goiano - Rio Verde Campus, for the opportunity of professional qualification and personal growth. 


\section{SUBMISSION STATUS}

Received: 20 mar., 2017

Accepted: 26 oct., 2017

\section{CORRESPONDENCE TO}

\section{Leandro Carlos}

Programa de Pós-graduação em Ciências

Agrárias, Departamento de Agronomia, Instituto

Federal Goiano - IF Goiano, Rodovia Sul Goiana, Km 01, Zona Rural, CP 66, CEP 75901-970,

Rio Verde, GO, Brasil

e-mail: leandro.carlos@ifgoiano.edu.br

\section{REFERENCES}

Almeida EIIB, Corrêa MCM, Crisostomo LA, Araújo NA, Silva JCV. Nitrogênio e potássio no crescimento de mudas de pitaia [Hylocereus undatus (Haw.) Britton \& Rose]. Revista Brasileira de Fruticultura 2014; 36(4): 1018-1027. http://dx.doi.org/10.1590/0100-2945-296/13.

Bailão EFLC, Devilla IA, Conceição EC, Borges LL. Bioactive compounds found in brazilian Cerrado Fruits. International Journal of Molecular Sciences 2015; 16(1): 23760-23783. http://dx.doi.org/10.3390/ijms161023760. PMid:26473827.

Botrel DA, Rodrigues ICB, Souza HJB, Fernandes RVB. Application of inulin in thin-layer drying process of araticum (Annona crassiflora) pulp. Lebensmittel-Wissenschaft + Technologie 2016; 69(1):32-39. http://dx.doi.org/10.1016/j. lwt.2016.01.018.

Braga JR Fo, Naves RV, Chaves LJ, Souza ERB, Mazon LT, Silva LB. Germinação de sementes e emergência de plântulas de araticum oriundos do cerrado de goiás. Bioscience Journal 2014; 30(1): 74-81.

Carlos L, Venturin N, Macedo RLG, Venturin RP, Soares AAVS, Toledo FHSF. Growth and mineral nutrition in Annona crassiflora Mart. Seedlings subjected to nutrient deprivation. Australian Journal of Basic and Applied Sciences 2014; 8(13): 379-384.

Carnevali NHS, Marchetti ME, Vieira MC, Carnevali TO, Ramos DD. Eficiência nutricional de mudas de Stryphnodendron polyphyllum em função de nitrogênio e fósforo. Ciência Florestal 2016; 26(2): 449-461. http:// dx.doi.org/10.5902/1980509822746.

Cruz CAF, Paiva HN, Cunha ACMCM, Neves JCL. Resposta de mudas de Senna macranthera cultivadas em Argissolo Vermelho-Amarelo a macronutrientes. Ciência Florestal 2011;21(1): 63-76. http://dx.doi.org/10.5902/198050982748.

Cruz CAF, Paiva HN, Neves JCL, Cunha ACMCM. Resposta de mudas de Senna macranthera (Dc. Ex Collad.)
H.s. Irwin \& barnaby (fedegoso) cultivadas em Latossolo Vermelho- Amarelo distrófico a macronutrientes. Revista Árvore 2010; 34(1): 13-24. http://dx.doi.org/10.1590/ S0100-67622010000100002.

Deng Q, Hui D, Luo Y, Elser J, Wang YP, Loladze I et al. Down-regulation of tissue N:P ratios in terrestrial plants by elevated $\mathrm{CO}_{2}$ Ecological Society of America 2015; 96(12): 3354-3362. PMid:26909440.

Dickson A, Leaf AL, Hosner JF. Quality appraisal of white spruce and white pine seedling stock in nurseries. Forestry Chronicle 1960; 36(1): 10-13. http://dx.doi.org/10.5558/ tfc36010-1.

Duarte ML, Paiva HN, Alves MO, Freitas AF, Maia FF, Goulart LML. Crescimento e qualidade de mudas de vinhático (Platymeniafoliolosa Benth.) em resposta à adubação com potássio e enxofre. Ciência Florestal 2015; 25(1): 221-229. http://dx.doi.org/10.5902/1980509817480.

Empresa Brasileira de Pesquisa Agropecuária - EMBRAPA. Manual de métodos de análise de solo. 2. ed. Rio de Janeiro: Centro Nacional de Pesquisas de Solos; 1997. 212 p.

Empresa Brasileira de Pesquisa Agropecuária - EMBRAPA. Sistema brasileiro de classificação de solos. Rio de Janeiro: Embrapa Solos; 2006. 412 p.

Empresa Brasileira de Pesquisa Agropecuária - EMBRAPA. Manual de análises químicas de solos, plantas e fertilizantes. 2. ed. Brasília: Embrapa Informação Tecnológica; 2009. $627 \mathrm{p}$.

Farias SCC, Silva ML Jr, Ruivo MLP, Rodrigues PG, Melo VS, Costa AR et al. Phosphorus forms in ultisol submitted to burning and trituration of vegetation in Eastern Amazon. Revista Brasileira de Ciência do Solo 2016; 40(1): 1-20.

Feitosa DG, Maltoni KL, Cassiolato AMR, Paiano MO. Crescimento de mudas de gonçalo-alves (Astronium fraxinifolium) sob diferentes fontes e doses de nitrogênio. Revista Árvore 2011; 35(3): 401-411. http://dx.doi. org/10.1590/S0100-67622011000300004.

Ferreira DF. Sisvar: a computer statistical analysis system. Ciência e Agrotecnologia 2011; 35(6): 1039-1042. http:// dx.doi.org/10.1590/S1413-70542011000600001.

Gonçalves EO, Paiva HN, Lima Neves JC, José Mauro Gomes JM. Crescimento de mudas de sansão-do-campo (Mimosa caesalpiniaefolia Benth.) sob diferentes doses de macronutrientes. Scientia Forestalis 2010; 38(88): 599-609.

Gonçalves EO, Paiva HN, Neves JCL, Gomes JM. Nutrição de mudas de angico-vermelho (Anadenanthera macrocarpa (Benth.) Brenan) submetidas a doses de N, P, K, Ca e Mg. Revista Árvore 2012; 36(2): 219-228. http://dx.doi. org/10.1590/S0100-67622012000200003.

Gonçalves EO, Paiva HN, Neves JCL, Klippel VH, Caldeira MVW. Crescimento de jacarandá-da-bahia (Dalbergia nigra ((Vell.) Fr. All. exBenth)) sob diferentes doses de NPK. Cerne 2014; 20(3): 493-500. http://dx.doi.org/10. 1590/01047760201420031220. 
International Association for Engeneering Geology IAEG. Classification of rocks and soils for engeneering geological mapping. Bulletin of Engineering Geology and the Environment 1979; 19(1): 355-371.

Lötter D, van Garderen EA, Tadross M, Valentine AJ. Seasonal variation in the nitrogen nutrition and carbon assimilation in wild and cultivated Aspalathus linearis (rooibos tea). Australian Journal of Botany 2014; 62(1): 65-73. http://dx.doi.org/10.1071/BT13237.

Magadlela A, Kleinert A, Dreyer LL, Valentine AJ. Lowphosphorus conditions affect the nitrogen nutrition and associated carbon costs of two legume tree species from a Mediterranean-type ecosystem. Australian Journal of Botany 2014; 62(1): 1-9. http://dx.doi.org/10.1071/BT13264.

Mendes KR, Marenco RA, Magalhães NS. Crescimento e eficiência fotossintética de uso do nitrogênio e fósforo em espécies florestais da Amazônia na fase juvenil. Revista Árvore 2013; 37(4): 707-716. http://dx.doi.org/10.1590/ S0100-67622013000400014.

Oliveira CJ, Pereira WE, Mesquita FO, Medeiros JS, Alves AS. Crescimento inicial de mudas de açaizeiro em resposta a doses de nitrogênio e potássio. Revista Verde 2011; 6(2): 227-237.

Pedó T, Aumonde TZ, Martinazzo EG, Villela FA, Lopes NF, Mauch CR. Análise de crescimento de plantas de rabanete submetidas a doses de adubação nitrogenada. Bioscience Journal 2014; 30(1): 1-7.

Rajan J, Veilumuthu Anandhan S. Influence of nitrogen and potassium on root nutrient and root CEC of differentte a cultivars (Camelliasinensis, C. assamicaand C. assamica spp. Lasiocalyx). Rhizosphere 2016; 1(1): 36-44. http:// dx.doi.org/10.1016/j.rhisph.2016.07.004.

Ribeiro PC, Lemos-Filho JP, Buzatti RO, Lovato MB, Heuertz M. Species-specific phylogeographical patterns and Pleistocene east-west divergence in Annona (Annonaceae) in the Brazilian Cerrado. Botanical Journal of the Linnean Society 2016a; 181(1): 21-36. http://dx.doi. org/10.1111/boj.12394.

Ribeiro PC, Souza ML, Muller LAC, Ellis VA, Heuertz M, Lemos-Filho JP et al. Climatic drivers of leaf traits and genetic divergence in the tree Annona crassiflora: a broad spatial survey in the Brazilian savannas. Global Change Biology 2016b; 22(11): 3789-3803. http://dx.doi. org/10.1111/gcb.13312. PMid:27062055.
Saiz-Fernández I, Diego M, Sampedro MC, Mena-Petite A, Ortiz-Barredo A, Lacuesta M. High nitrate supply reduces growth in maize, from cell to whole plant. Journal of Plant Physiology 2015; 173(1): 120-129. http://dx.doi. org/10.1016/j.jplph.2014.06.018. PMid:25462086.

Silva EAA, Melo DLB, Davide AC, Bode N, Abreu GB, Faria JMR et al. Germination Ecophysiology of Annona crassiflora Seeds. Annals of Botany 2007; 99(5): 823-830. PMid:17329406.

Sousa GG, Viana TVA, Pereira ED, Albuquerque AHP, Marinho AB, Azevedo BM. Fertirrigação potássica na cultura do morango no litoral Cearense. Bragantia 2014; 73(1): 1-6. http://dx.doi.org/10.1590/brag.2014.006.

Souza NH, Marchetti ME, Carnevali TO, Ramos DD, Scalon SPQ, Silva EF. Estudo nutricional da canafístula (i): crescimento e qualidade de mudas em resposta à adubação com nitrogênio e fósforo. Revista Árvore 2013; 37(4): 717-724. http://dx.doi.org/10.1590/S010067622013000400015 .

Souza PH, Paiva HN, Neves JCL, Gomes JM, Marques LS. Crescimento e qualidade de mudas de Senna macranthera (Dc. Ex Collad.) Irwin et Barn. em resposta à calagem. Revista Árvore 2010; 34(2): 233-240. http://dx.doi. org/10.1590/S0100-67622010000200005.

Tucci CAF, Santos JZL, Silva CH Jr, Souza PA, Batista IMP, Venturin N. Desenvolvimento de mudas de Swietenia macrophylla em resposta a nitrogênio, fósforo e potássio. Floresta 2011; 41(3): 471-490. http://dx.doi.org/10.5380/ rf.v41i3.24039.

Valadares SV, Silva LF, Valadares RV, Fernandes LA, Neves JCL, Sampaio RA. Plasticidade fenotípica e frações fosfatadas em espécies florestais como resposta à aplicação de fósforo. Revista Árvore 2015; 39(2): 225-232. http:// dx.doi.org/10.1590/0100-67622015000200002.

van Raij B. Avaliação da fertilidade do solo. Piracicaba: Associação Brasileira para Pesquisa da Potassa e do Fosfato; 1981.142 p.

Zhang JL, Zhang SB, Chen YJ, Zhang YP, Poorter L. Nutrient resorption is associated with leaf vein density and growth performance of dipterocarp tree species. Journal of Ecology 2015; 103(1): 541-549. http://dx.doi. org/10.1111/1365-2745.12392. 